\title{
PHYTODIVERSITY IN RELATION TO SOME ENVIRONMENTAL FACTORS OF SOME WETLAND HABITATS
}

\author{
Md Almujaddade Alfasane", Safia Parveen ${ }^{1}$, Naheed Mansoor ${ }^{1}$, \\ Mahmoud Moustafa ${ }^{2,3}$ ANd Ahmed Al-Emam ${ }^{4,5}$ \\ Department of Botany, University of Dhaka, Dhaka 1000, Bangladesh
}

Keywords: Phytodiversity, Environmental factors, Ponds, Wetland habitats

\begin{abstract}
The present research work was carried out on phytodiversity in relation to some environmental factors of three ponds namely, Pond-1, Pond-2 and Pond-3 of Zanjira upazila at Shariatpur district, Bangladesh where a total of 13 parameters were measured for one year. Monthly average different parameters of three ponds varied : air temperature from $23.5-36.50^{\circ} \mathrm{C}$, water temperature $21-30.50^{\circ} \mathrm{C}, \mathrm{pH} 7.10-8.50$, TDS $55-227 \mathrm{mg} / \mathrm{l}$, EC 103-463 $\mu \mathrm{S} / \mathrm{cm}$, DO 2.90-19.94 mg/l, alkalinity 0.73-5.40 meq/l, SRP 7.11-229.84 $\mu \mathrm{g} / \mathrm{l}$, SRS0.84-13.34 $\mathrm{mg} / \mathrm{l}, \mathrm{NO}_{3}-\mathrm{N} 0.02-0.96 \mathrm{mg} / \mathrm{l}$, chla1. 18-31.97 $\mu \mathrm{g} / \mathrm{l}$, phaeopigment 0.26-5.46 $\mu \mathrm{g} / \mathrm{l}$ and phytoplankton density $6.50-119.50 \times 10^{6} \mathrm{ind} / \mathrm{l}$. The total number of 122 species of phytoplankton were recorded in the studied ponds. Phytoplankton density showed positive correlation with air temperature, water temperature, $\mathrm{pH}$, TDS, EC, alkalinity and SRP for Pond-1. Phytoplankton density showed positive correlation with $\mathrm{pH}$, TDS, EC, DO and alkalinity for Pond-2. On the other hand phytoplankton density of Pond-3 showed positive correlation with air temperature, water temperature, TDS, EC, alkalinity, SRP, SRS, $\mathrm{NO}_{3}-\mathrm{N}$ and chlorophyll- $a$. During the period of present investigation some aquatic plants were found to grow in those shallow margins of the studied three ponds. Results indicated that Pond-1 is in a position undergoing eutrophic status, Pond-2 and Pond-3 are in the oligotrophic status. If the anthropogenic disturbances are continued in these ponds, it is likely that in near future these ponds would turn to eutrophic.
\end{abstract}

\section{Introduction}

Ponds and rivers are the most common aquatic ecosystems of Bangladesh. Ponds biological system might be characterized as shallow still water body having littoral zone involved by macrophyte and where the limnetic and prefunded zones are little or truant.The physical and chemical factors of the water body play a great role for aquatic organisms where organisms are totally dependent on good water quality for their life support. Poor water quality can cause massive death of living organisms. Various factors like temperature, nutrients, $\mathrm{pH}$, alkalinity, dissolved oxygen play an important role for the growth and density of phytoplankton, on which zooplankton and some higher consumer depends for their existence (BAFRU 1990, Jerin et al. 2012). Periodic disturbances caused by seasonal changes of discharge are important in understanding the development of phytoplankton (Balasingh 2010, Pramanik et al. 2011). Phytoplankton contribute significantly towards the very initial input of organic matter into the pelagic grazing food chain resulting the production of fish (Pramanik et al. 2011).

Phytoplankton may be used as excellent proxies for detecting changes in the water column as a result of anthropogenic activities (Nishat et al. 1993). The issue of phytoplankton composition has gained increasing importance as a consequence of this putative increase in eutrophication (Smayda 1992).

\footnotetext{
*Author for correspondence: <mujaddade@yahoo.com>. ${ }^{1}$ Eden Mohila College, Dhaka, Bangladesh. ${ }^{2}$ Department of Biology, College of Science, King Khalid University, 9004, Abha, Kingdom of Saudi Arabia (KSA). ${ }^{3}$ Department of Botany and Microbiology, Faculty of Science, South Valley University, Qena, Egypt, ${ }^{4}$ Department of Pathology, College of Medicine, King Khalid University, Abha, Kingdom of Saudi Arabia, ${ }^{5}$ Department of Forensic Medicine and Clinical Toxicology, Faculty of Medicine, Mansoura University, Mansoura, Egypt.
} 
During recent year great concern for inland freshwater resources has been increased because they are affected in different ways by all kinds of anthropogenic activities (Nishat et al. 1993). In Bangladesh, both in village and urban areas and on the whole water bodies are reported to cover about $1.13 \%$ of the total area of Bangladesh with a great potentiality of biological productivity (Khondker 1995). The total pond area of Bangladesh is about 1,46,890 hectare (Khondker 1995). Therefore the hydrobiological investigations on water bodies are needed for Asian countries.

There are some reports on hydrobiological investigations in various ponds (Khondker 1995, Alfasane et al. 2002, 2003). In Bangladesh so far 100 hydrobiological investigations were completed on ponds biological system (FAP-17, 1993).

In Bangladesh so far no research on phytodiversity in relation to some environmental factors of three ponds of Zanjiraupazila at Shariatpur district, Bangladesh were carried out. Thus the present study aimed to investigate phytodiversity in relation to some environmental factors of three ponds, popularly known as Dilu Mridha's pond, Faraz Ali Pathan's pond and Nazrul Akand's pond of Zanjira upazila at Shariatpur district, Bangladesh.

\section{Materials and Methods}

The present research work was carried out on phytodiversity in relation to some environmental factors of three ponds namely, Pond-1 (P-1), Pond-2 (P-2) and Pond-3 (P-3) of Monai Chhaiyalerkandi village, Zanjira upazila at Shariatpur district, about $42 \mathrm{~km}$ south of Dhaka, the capital of Bangladesh where a total of 13 parameters were measured for one year study. There are one or several ponds in front or back side of every house in this village. These ponds which were dug out manually for the domestic purpose play important role in everyday life of the inhabitants living around them. Status of the selected three old ponds are: P-1 (23 $35^{\prime} 1418^{\prime \prime} \mathrm{N}$, $\left.90^{\circ} 31^{\prime} 2504 " \mathrm{E}\right)$, P-2 (23 $\left.35^{\prime} 1342^{\prime \prime} \mathrm{N}, 90^{\circ} 31^{\prime} 3146 " \mathrm{E}\right)$ and P-3 (25 $\left.05^{\prime} 1360^{\prime \prime} \mathrm{N}, 90^{\circ} 38^{\prime} 823^{\prime \prime} \mathrm{E}\right)$. During the present research a total of 36 samples were collected between 7.30 and $9.30 \mathrm{am}$. After collection, all samples were preserved in an insulated Ice box using cool packs and were brought to the National Professor AKM Nurul Islam laboratory (Phycology, Limnology and Hydrobiology), University of Dhaka for analysis. The preserving temperature was $\geq 10^{\circ} \mathrm{C}$ and processed within $24 \mathrm{hrs}$ of collection. Air temperature, water temperature, secchi depth, $\mathrm{pH}$, total dissolved solids (TDS) and conductivity were measured in situ using portable devices. Alkalinity was determined after Mackereth et al. (1978) and dissolved oxygen (DO) and soluble reactive silicate (SRS) after Wetzel and Likens (1979), soluble reactive phosphorus (SRP) and nitrate nitrogen $\left(\mathrm{NO}_{3}-\mathrm{N}\right)$ after Murphy and Rilley (1962) and Müller and Wiedemann (1955). Chlorophyll- $a$ and phaeopigment were determined after Marker et al. (1980). Samples of Phytoplankton were collected by sedimentation technique with Lugol's solution and quantification of plankton was done with the help of a HBCC (Helber bacterial counting chamber, having a fixed volume $(0.01 \mathrm{ml})$ under compound microscope, Nikon (Optiphot, UFX-11A) fitted with a camera (Nikon FX-35 WA, Japan). Pearson correlation was done (SPSS v20) to find out the relationship between the environmental factors and total phytoplankton density.

\section{Results and Discussion}

The present discussion is based on the phytodiversity and physico-chemical parameters, together with their relationships among themselves and their comparison with other similar environments studied elsewhere (Tables 1-5). Range of monthly average air temperature was recorded $24-34.50{ }^{\circ} \mathrm{C}, 23.50-36.50{ }^{\circ} \mathrm{C}$ and $24.50-35^{\circ} \mathrm{C}$ for P-1, P-2 and P-3, respectively. Seasonal highest mean air temperature was recorded during summer $33.38^{\circ} \mathrm{C}$ in $\mathrm{P}-2$ (Table 2) and lowest 
Table 1. Seasonal mean values $( \pm$ SD) of physico-chemical and biological variables in Pond-1.

\begin{tabular}{|c|c|c|c|c|}
\hline Parameters & Summer & Monsoon & Autum & Winter \\
\hline Air temp. $\left({ }^{\circ} \mathrm{C}\right)$ & $32.50 \pm 2.42$ & $30.17 \pm 2.57$ & $29.50 \pm 1.80$ & $27.75 \pm 2.47$ \\
\hline Water temp. $\left({ }^{\circ} \mathrm{C}\right)$ & $27.50 \pm 1.91$ & $27.33 \pm 2.52$ & $27.17 \pm 0.76$ & $23.50 \pm 2.12$ \\
\hline $\mathrm{pH}$ & $7.78 \pm 0.31$ & $7.70 \pm 0.10$ & $7.73 \pm 0.29$ & $7.30 \pm 0.28$ \\
\hline TDS(mgl) & $127.25 \pm 28.39$ & $91.33 \pm 7.23$ & $102.33 \pm 14.19$ & $103.00 \pm 14.14$ \\
\hline $\mathrm{EC}(\mu \mathrm{S} \backslash \mathrm{cm})$ & $266.50 \pm 58.38$ & $200.00 \pm 26.00$ & $215.67 \pm 19.04$ & $164.50 \pm 67.18$ \\
\hline $\mathrm{DO}(\mathrm{mgl})$ & $4.18 \pm 1.33$ & $4.20 \pm 0.70$ & $3.60 \pm 0.63$ & $3.35 \pm 0.21$ \\
\hline Alkal.(meql) & $2.78 \pm 1.78$ & $1.9 \pm 0.2$ & $1.73 \pm 0.57$ & $2.2 \pm 1.13$ \\
\hline $\operatorname{SRP}(\mu \mathrm{gl})$ & $81.75 \pm 36.82$ & $136.42 \pm 20.13$ & $133.68 \pm 109.18$ & $160.57 \pm 96.89$ \\
\hline $\mathrm{SRS}(\mathrm{mgll})$ & $2.71 \pm 2.11$ & $3.13 \pm 0.16$ & $3.09 \pm 0.07$ & $3.37 \pm 1.66$ \\
\hline $\mathrm{NO}_{3}-\mathrm{N}(\mathrm{mgll})$ & $0.58 \pm 0.33$ & $0.21 \pm 0.06$ & $0.07 \pm 0.07$ & $0.05 \pm 0.02$ \\
\hline Chl $a(\mu \mathrm{gl})$ & $18.84 \pm 9.06$ & $9.81 \pm 0.34$ & $9.92 \pm 1.59$ & $11.25 \pm 5.86$ \\
\hline Phae ( $\mu \mathrm{gll})$ & $3.47 \pm 1.91$ & $2.11 \pm 0.08$ & $1.86 \pm 0.58$ & $2.3 \pm 1.08$ \\
\hline $\begin{array}{l}\text { Phytoplankton density } \\
\left(\times 10^{6} \text { ind } / 1\right)\end{array}$ & $68.25 \pm 45.18$ & $73.83 \pm 1.04$ & $69.67 \pm 47.93$ & $41.75 \pm 6.72$ \\
\hline No of species & $15.25 \pm 4.65$ & $17.33 \pm 1.53$ & $17.00 \pm 6.56$ & $13.5 \pm 3.54$ \\
\hline
\end{tabular}

Table 2. Seasonal mean values $( \pm \mathrm{SD})$ of physico-chemical and biological variables in Pond-2.

\begin{tabular}{lcccc}
\hline Parameters & Summer & Monsoon & Autum & Winter \\
\hline Air temp. $\left({ }^{\circ} \mathrm{C}\right)$ & $33.38 \pm 3.73$ & $31.50 \pm 1.82$ & $28.83 \pm 1.76$ & $25.00 \pm 2.83$ \\
Water temp. $\left({ }^{\circ} \mathrm{C}\right)$ & $28.38 \pm 2.98$ & $28.00 \pm 1$ & $27.67 \pm 2.02$ & $22.00 \pm 1.41$ \\
pH & $7.58 \pm 0.26$ & $7.77 \pm 0.51$ & $7.93 \pm 0.15$ & $7.50 \pm 0.28$ \\
TDS $(\mathrm{mgll})$ & $113.25 \pm 29.68$ & $159.33 \pm 49.36$ & $183.67 \pm 60.93$ & $100.50 \pm 9.19$ \\
$\mathrm{EC}(\mu \mathrm{S} \backslash \mathrm{cm})$ & $234.50 \pm 58.93$ & $343.33 \pm 115.08$ & $378.67 \pm 122.62$ & $161.50 \pm 82.73$ \\
$\mathrm{DO}(\mathrm{mgl})$ & $9.36 \pm 1.99$ & $14.68 \pm 4.21$ & $11.73 \pm 2.43$ & $12.62 \pm 9.21$ \\
$\mathrm{Alkal} .(\mathrm{meql})$ & $1.19 \pm 0.33$ & $1.10 \pm 0.11$ & $1.31 \pm 0.44$ & $1.55 \pm 0.79$ \\
$\mathrm{SRP}(\mu \mathrm{gll})$ & $40.70 \pm 24.83$ & $39.14 \pm 46.77$ & $10.46 \pm 1.78$ & $13.53 \pm 2.76$ \\
$\mathrm{SRS}(\mathrm{mgll})$ & $7 \pm 3.86$ & $3.87 \pm 1.14$ & $4.86 \pm 1.19$ & $6.50 \pm 3.39$ \\
$\mathrm{NO} 3^{-\mathrm{N}}(\mathrm{mgll})$ & $0.39 \pm 0.33$ & $0.25 \pm 0.03$ & $0.24 \pm 0.03$ & $0.29 \pm 0.08$ \\
$\mathrm{Chl}(\mu \mathrm{g} \mathrm{gl})$ & $18.29 \pm 11.06$ & $19.98 \pm 7.88$ & $4.17 \pm 3.28$ & $8.61 \pm 1.22$ \\
Phae $(\mu \mathrm{gll})$ & $1.90 \pm 2.33$ & $3.18 \pm 1.35$ & $0.77 \pm 0.63$ & $0.54 \pm 0.29$ \\
Phytoplankton density & $18.55 \pm 13.09$ & $22.00 \pm 4.19$ & $38.83 \pm 26.10$ & $48.25 \pm 14.50$ \\
$\left(\times 10^{6}\right.$ ind/l) & & & & \\
No of species & $7.75 \pm 1.26$ & $20.33 \pm 3.06$ & $21.67 \pm 8.51$ & $14.00 \pm 2.83$ \\
\hline
\end{tabular}

seasonal mean air temperature was recorded during winter $25^{\circ} \mathrm{C}$ in P-2 (Table 2). During the study period, water temperature ranged $22-30^{\circ} \mathrm{C}, 21-30.50^{\circ} \mathrm{C}$ and $22.50-30^{\circ} \mathrm{C}$ for $\mathrm{P}-1, \mathrm{P}-2$ and $\mathrm{P}-3$, respectively. The highest seasonal mean value of water temperature was found during summer $28.38^{\circ} \mathrm{C}$ in P-2 (Table 2) and lowest seasonal mean value of water temperature was found during 
winter $22^{\circ} \mathrm{C}$ in P-2 (Table 2). Similar results in water temperature were reported by Chowdhury and Mamun (2006) in two fishpond of Khulna. Water temperature ranged between $19.1-34.5^{\circ} \mathrm{C}$ in one temple pond and $21.7-30.96^{\circ} \mathrm{C}$ in other temple pond of Cachar district in Assam, North East India (Banita et al. 2013).

There are some variations of $\mathrm{pH}$ among the studied three ponds ranging from 7.10-8.20, 7.208.20 and $7.40-8.10$ for $\mathrm{P}-1, \mathrm{P}-2$ and $\mathrm{P}-3$, respectively. However, the $\mathrm{pH}$ of water was closer to neutral or slightly alkaline. During the time of study, the $\mathrm{pH}$ showed a uniform fluctuation in three ponds. The highest seasonal mean value of $\mathrm{pH}$ was recorded during autumn 8.20 in P-3 (Table 3 ) and the lowest mean value was recorded during winter 7.30 in $\mathrm{P}-1$ (Table 1).The $\mathrm{pH}$ value in nine ponds of Airongmara, Assam, North East India were in a range from 6.9-7.82 (Bhuiyan and Gupta 2007), which is very close to the present results. Permanently alkaline pond was also recorded by Chowdhury and Mamun (2006), Kumar et al. (2012) and Alfasane et al. (2012).

Table 3. Seasonal mean values ( \pm SD) of physico-chemical and biological variables in Pond-3.

\begin{tabular}{|c|c|c|c|c|}
\hline Parameters & Summer & Monsoon & Autum & Winter \\
\hline Air temp. $\left({ }^{\circ} \mathrm{C}\right)$ & $32.00 \pm 3.46$ & $30.37 \pm 2.75$ & $27.33 \pm 1.53$ & $26.25 \pm 2.48$ \\
\hline Water temp. $\left({ }^{\circ} \mathrm{C}\right)$ & $26.88 \pm 2.02$ & $27.50 \pm 2.29$ & $27.33 \pm 3.06$ & $23.75 \pm 1.77$ \\
\hline $\mathrm{pH}$ & $7.75 \pm 0.29$ & $7.77 \pm 0.15$ & $8.20 \pm 0.26$ & $7.75 \pm 0.49$ \\
\hline TDS(mgl) & $112.00 \pm 51.45$ & $150.33 \pm 83.74$ & $140.33 \pm 16.56$ & $104 \pm 14.14$ \\
\hline $\mathrm{EC}(\mu \mathrm{S} \backslash \mathrm{cm})$ & $232.00 \pm 100.81$ & $303.00 \pm 163.15$ & $281.00 \pm 22.91$ & $214.50 \pm 31.82$ \\
\hline $\mathrm{DO}(\mathrm{mgl})$ & $14.04 \pm 6.95$ & $13.45 \pm 4.93$ & $10.31 \pm 1.70$ & $12.22 \pm 8.63$ \\
\hline Alkal.(meql) & $1.20 \pm 0.62$ & $1.35 \pm 0.46$ & $1.59 \pm 0.19$ & $1.31 \pm 0.27$ \\
\hline $\mathrm{SRP}(\mu \mathrm{gl})$ & $17.64 \pm 12.69$ & $17.62 \pm 0.97$ & $16.64 \pm 2.42$ & $13.65 \pm 6.82$ \\
\hline SRS(mgll) & $5.28 \pm 5.74$ & $2.45 \pm 0.63$ & $5.10 \pm 1.62$ & $11.00 \pm 2.33$ \\
\hline $\mathrm{NO}_{3}-\mathrm{N}(\mathrm{mgll})$ & $0.05 \pm 0.05$ & $0.02 \pm 0.01$ & $0.03 \pm 0.02$ & $0.03 \pm 0.01$ \\
\hline Chla $(\mu \mathrm{gl})$ & $6.51 \pm 1.18$ & $19.03 \pm 3.83$ & $11.53 \pm 3.78$ & $7.11 \pm 1.68$ \\
\hline Phae ( $\mu \mathrm{gll})$ & $1.09 \pm 0.56$ & $4.62 \pm 0.56$ & $2.87 \pm 1.52$ & $2.04 \pm 1.16$ \\
\hline $\begin{array}{l}\text { Phytoplankton density } \\
\left(\times 10^{6} \text { ind } / \mathrm{l}\right)\end{array}$ & $13.38 \pm 7.10$ & $30.00 \pm 18.52$ & $17 \pm 7.00$ & $21.75 \pm 0.35$ \\
\hline No of species & $7.75 \pm 1.71$ & $15.00 \pm 6.25$ & $11.67 \pm 3.51$ & $10 \pm 2.83$ \\
\hline
\end{tabular}

High Total Dissolved Solids (TDS) value in the effluent is not desireable because it increases density of water, reduces solubility of gases (like oxygen) and disturbs utility of water for drinking, irrigation and industrial purposes.There are some variations of TDS among the studied three pond which ranged from 83-146 mg/l,73-210 mg/land 55-212 mg/l for P-1, P -2 and P-3, respectively. The highest seasonal mean value of TDS was recorded during autumn $183.67 \mathrm{mg} / \mathrm{l}$ in P-2 (Table 2) and the lowest value was recorded during monsoon 91.33 $\mathrm{mg} / \mathrm{l}$ in P-1 (Table 1). Similar observations were also made by Alfasane et al. (2003).

Electrical conductivity (EC) was found to range from 117-296 $\mu \mathrm{S} / \mathrm{cm}, 103-435 \mu \mathrm{S} / \mathrm{cm}$ and 119 $430 \mu \mathrm{S} / \mathrm{cm}$ for P-1, P-2 and P-3, respectively. The highest seasonal mean value $(378.67 \mu \mathrm{S} / \mathrm{cm})$ of conductivity was recorded during autumn in P-2 (Table 2) and the lowest was recorded during winter $161.50 \mu \mathrm{S} / \mathrm{cm}$ in P-2 (Table 2). The present data are also in agreement with the data made by Alfasane et al. $(2003,2012)$. Salts or other chemicals that dissolve in water can break down 
into positively and negatively charged ions. These free ions in the water conduct electricity, so the water electrical conductivity depends on the concentration of ions. Salinity and TDS are used to calculate the EC of water, which helps to indicate the water's purity. The concentration of ions depends on the environment, movement and sources water. The soluble ions in the surface water originate primarily from solution of rock materials. Specific conductance of most natural water generally ranges from about 20 to $1500 \mu \mathrm{S} / \mathrm{cm}$. Similar observations were also made by Alfasane et al. (2003).

Dissolved oxygen (DO) levels are considered as most important indicator of a water body's ability to support desirable aquatic life.The average value of DO levels $(6.5 \mathrm{mg} / \mathrm{l})$ indicates the average quality of fresh water (Alfasane et al. 2003). It was observed that the range of DO was from $2.90-4.50 \mathrm{mg} / 1,6.11-19.54 \mathrm{mg} / \mathrm{land} 4.48-19.94 \mathrm{mg} / \mathrm{l}$ for P-1, P-2 and P-3, respectively. The highest and lowest seasonal mean DO were found during monsoon $14.68 \mathrm{mg} / \mathrm{l}$ in P-2 (Table 2) and during winter $3.35 \mathrm{mg} / \mathrm{l}$ in P-1 (Table 1). So it represents the average quality of fresh water for fish life and other aquatic life.Observations of DO concentration were recorded in the many others experiment ranged from 9.0 to $12.0 \mathrm{mg} / \mathrm{l}$ in some ponds of greater Noakhali district (Begum and Alam 1987). DO concentration in some rural ponds of greater Comilla was reported to range between 8.5 and $14 \mathrm{mg} / \mathrm{l}$ (Alfasane et al. 2003). There are some variations of Alkalinity among the three ponds ranging from $1.10-5.40 \mathrm{meq} / \mathrm{l}, 0.73-1.68 \mathrm{meq} / \mathrm{land} 0.65-2.02 \mathrm{meq} / \mathrm{l}$ for P-1, P-2 and P3 , respectively. Seasonally the highest value of Alkalinity was recorded as 2.78 meq/l during summer in P-1 (Table 1). On the other hand, lowest value $1.10 \mathrm{meq} / \mathrm{l}$ was recorded during monsoon in P-2 (Table 2). This result is in agreement with the findings of Chowdhury and Mamun (2006), Pramaniket al. (2011), Jerin et al. (2012) and Alfasane et al. (2002).

The concentration of soluble reactive phosphorus (SRP) was found to range from 53.74-229.08 $\mu \mathrm{g} / \mathrm{l}, 0.73-1.63 \mu \mathrm{g} / \mathrm{l}$ and $7.11-35.83 \mu \mathrm{g} / \mathrm{l}$ for P-1, P-2and P-3, respectively. Seasonally the highest value of SRP was recorded as $160.57 \mu \mathrm{g} / \mathrm{l}$ during winter in P-1 (Table 1). On the other hand, the lowest value $10.46 \mu \mathrm{g} / \mathrm{l}$ was recorded during autumn in P-2 (Table 2). It indicates that the conditions of waters of P-2 and P-3 water were good.

The concentration of soluble reactive silicate (SRS) ranged from 1.21-5.80 mg/l, 1.46-10.26 $\mathrm{mg} / \mathrm{l}, 0.84-13.34 \mathrm{mg} / \mathrm{l}$ for P-1, P-2 and P-3, respectively. The highest seasonal mean value of SRS $(11 \mathrm{mg} / \mathrm{l})$ was recorded during winter in P-3 and the lowest $(2.45 \mathrm{mg} / \mathrm{l})$ was recorded during monsoon in P-3 (Table 3). Mean concentration of SRS fluctuated in the same order of magnitude as those observed from northern part of Bangladesh and Dhaka Metropolis (BAFRU 1990). In some polluted water silica concentration was recorded as high as $50.0 \mathrm{mg} / \mathrm{l}$ which is near the mean value of study ponds (Khondker 1995). The concentration of $\mathrm{NO}_{3}-\mathrm{N}$ varied from $0.02-0.96 \mathrm{mg} / \mathrm{l}$, 0.07-85 mg/l,0.04-0.96 mg/l, for P-1, P-2 and P-3, respectively. The highest seasonal mean value $(0.53 \mathrm{mg} / \mathrm{l})$ of $\mathrm{NO}_{3}-\mathrm{N}$ was recorded during summer in P-1 (Table 1) and the lowest mean value $(0.02 \mathrm{mg} / \mathrm{l})$ was recorded during monsoon in P-3 (Table 3 ).

The concentration of chlorophyll $a$ (chl. $a$ ) varied from 7.10-31.97 $\mu \mathrm{g} / \mathrm{l}, 1.18-28.57 \mu \mathrm{g} / \mathrm{l}$ and 4.74-23.37 $\mu \mathrm{g} / \mathrm{l}$ for P-1, P-2 and P-3, respectively. The highest seasonal mean value $19.98 \mu \mathrm{g} / \mathrm{l}$ of chlorophyll $a$ was recorded during monsoon in Pond-2 (P-2) and the lowest value $4.17 \mu \mathrm{g} / \mathrm{l}$ was recorded during autumn in P-2 (Table 2). The higher biomass value indicates a eutrophic nature of the above mentioned pond. On the other hand, low biomass value 8.25 was recorded from metropolis Shahidullah Hall pond of Dhaka University campus. Phaeopigment concentration varied from 1.47-5.46 $\mu \mathrm{g} / 1,0.31-5.39 \mu \mathrm{g} / 1$ and $0.26-5.27 \mu \mathrm{g} / \mathrm{l}$ for P-1, P-2 and P-3, respectively. The highest seasonal mean value $(4.62 \mu \mathrm{g} / \mathrm{l})$ of phaeopigment was recorded during monsoon in $\mathrm{P}$ 3 (Table 3 ) and the lowest $(0.54 \mu \mathrm{g} / \mathrm{l})$ was recorded during winter in P-2 (Table 2). Greater ratio of pheophytin- $a$ to chlorophyll- $a$ indicates poorer water quality (Khondker 1995). 
The recorded seasonal mean value of density of phytoplankton population in the three ponds presented in Tables 1-3 revealed that the total phytoplankton population was highest $119 \times 10^{6} \mathrm{ind} / 1$ in March in P-1. The lowest number was recorded in April $6.50 \times 10^{6}$ ind/l in P-2 (Table 2). The highest seasonal mean phytoplankton density $\left(73.83 \times 10^{6}\right.$ ind/l) was recorded during monsoon in P-1 and the lowest $\left(13.38 \times 10^{6}\right.$ ind/l) was recorded during summer in P-3 (Table 3$)$.

In the present investigation 46, 41, 54 genera were recorded in the phytoplankton communities for P-1, P-2 and P-3, respectively. The genera were recorded from P-1, P-2 and P-3 belonging to six classes (Cyanophyceae, Chlorophyceae, Euglenophyceae, Bacillariophyceae, Cryptophyceae and Dinophyceae (Table 4).

Table 4. Number of phytoplankton genera from different classes of algae in three ponds.

\begin{tabular}{lccc}
\hline \multirow{2}{*}{ Class } & \multicolumn{3}{c}{ No. of genera and Percentage } \\
\cline { 2 - 4 } & Pond-1 & Pond-2 & Pond-3 \\
\hline Chlorophyceae & $18(39.13 \%)$ & $17(42.50 \%)$ & $21(38.89 \%)$ \\
Cryptophyceae & $03(6.52 \%)$ & $2(5.00 \%)$ & $03(5.56 \%)$ \\
Bacillariophyceae & $09(23.50 \%)$ & $9(22.50 \%)$ & $9(22.50 \%)$ \\
Euglenopyceae & $5(10.87 \%)$ & $7(17.50 \%)$ & $5(9.26 \%)$ \\
Cyanophyceae & $10(21.74 \%)$ & $5(12.50 \%)$ & $12(22.22 \%)$ \\
Dinophyceae & $1(2.17 \%)$ & $1(2.50 \%)$ & $4(7.42 \%)$ \\
Total & 46 & 41 & 54 \\
\hline
\end{tabular}

From the studied three ponds Scenedesmus, Crucigeniaand Cosmarium and Pandorina were found to be abundant in number rather than other green algae in P-1. Cyclotella and Navicula were found to be most dominant diatoms in P-2. Merismopedia and Oscillatoria were found to be dominant blue green algae for P-1, Euglena, Lepocinclis, and Peridinium were found to be in a large number other than any representative of its group in P-2 and P-3. This observation is quite different from the findings of Kumar et al. (2012) in two High Altitude Himalayan Ponds, Badrinath, Uttarakhand, India. Maximum abundance and diversity of Cyanophyceae, an all Euglenophyceae were recorded in the months of April and May (Chowdhury and Mamun 2006).

Number of algal genera recorded were very close to each other in three ponds (Table 4). Genus level percentage composition showed that Chlorophyceae dominates and occupied 39.13, 42.50 and $38.83 \%$ for P-1, P-2 and P-3, respectively followed by Cyanophyceae $21.74 \%$ for P-1, $22.50 \%$ for P-2 and $22.22 \%$ for P-3; Bacillariophyceae $19.57 \%$ for P-1, $17.50 \%$ for P-2, and $16.67 \%$ for P-3; Euglenophyceae $10.87 \%$ for P-1, $12.50 \%$ for P-2 and 9.26\% for P-3; Cryptophyceae $6.52 \%$ for P-1, 5.00\% for P-2 and 5.62\% for P-3. Dinophyceae can be treated as minor group $2.17 \%$ for P-1, 2.50\% for P-2 and 7.42\% for P-3. Kumar et al. (2012) also recorded maximum number of phytoplankton from the class Chlorophyceae followed by Bacillariophyceae, Cyanophyceae, Euglenophyceae, Dinophyceae and Xanthophyceae, respectively.

At species level a total 98, 122 and 105 species were recovered from P-1, P-2 and P-3, respectively (Table 5). Maximum number of species $33.67 \%$ for P-1, $34.42 \%$ for $\mathrm{P}-2$ and $39.05 \%$ for P-3 among the flora studied was represented by the Chlorophyceae. Next was the Euglenophyceae $31.96 \%$ P-2, 26.53\% for P-1 and $18.09 \%$ for P-3 followed by Bacillariophyceae, Cyanophyceae, Cryptophyceae and least one Dinophyceae (Table 5). Another experiment in nine ponds showed that major taxa were present belonging to the class Chlorophyceae, 
Bacillariophyceae, Cyanophyceae, Euglenophyceae, where, Chlorophyceae is the most common group of phytoplankton (Bhuiyan and Gupta 2007, Alfasane et al. 2003).

Total number of phytoplankton species recorded in the present study was 122 of which 110 species were previously reported for Bangladesh and 12 species were found as new reports. Class wise distributions of species are presented in Table 5. Begum and Alam (1987) identified a total number of 69 taxa in the studied two ponds belonging to the classes Cyanophyceae, Chlorophyceae, Chrysophyceae, Xanthophyceae, Cryptophyceae and Dinophyceae.

Table 5. Number of phytoplankton species recorded from different classes of algae in three ponds.

\begin{tabular}{lccc}
\hline \multirow{2}{*}{ Class } & \multicolumn{3}{c}{ No. of species and percentage } \\
\hline Chlorophyceae & $33(33.67 \%)$ & Pond-2 & Pond-3 \\
Cryptophyceae & $3(3.06 \%)$ & $52(34.42 \%)$ & $41(39.05 \%)$ \\
Bacillariophyceae & $19(19.39 \%)$ & $16(13.11 \%)$ & $5(4.76 \%)$ \\
Euglenopyceae & $26(26.53 \%)$ & $39(31.96 \%)$ & $17(16.19 \%)$ \\
Cyanophyceae & $16(16.33 \%)$ & $19(15.57 \%)$ & $19(18.09 \%)$ \\
Dinophyceae & $1(1.4 \%)$ & $1(1.85 \%)$ & $4(18.09 \%)$ \\
Total & 98 & 122 & 105 \\
\hline
\end{tabular}

The dominant status of Chlorophyceae was also observed in a perennial pond in Kanyakumari, Tamil Nadu (Balasingh 2010). In the present study the dominance of Chlorophyceae showed their tendency towards mesotrophy (Banita et al. 2013).

During the period of present investigation different types of aquatic plants, namely, Pithophora sp. and other macrophytes namely, Eichhornia sp., Pistia sp., Ipomoe sp., Salvania sp., Cyperus sp., Marsilea sp., Lemna sp. and some other aquatic grasses were found to grow in those shallow margins of the studied three ponds.

Phytoplankton density showed positive correlation with air and water temperature, $\mathrm{pH}$, TDS, EC, alkalinity and SRP for P-1. For P-2 phytoplankton density showed positive correlation with $\mathrm{pH}, \mathrm{TDS}, \mathrm{EC}, \mathrm{DO}$ and alkalinity. On the other hand phytoplankton density of P-3 showed positive correlation with air and water temperature, TDS, conductivity, alkalinity, SRP, SRS, $\mathrm{NO}_{3}-\mathrm{N}$ and chlorophyll- $a$.

From the overall study it may be concluded that three ponds of Zanjira upazila at Shariatpur district are undergoing organic pollution and are presently in the undergoing eutrophic status in P1 and oligotrophic status in P-2 and P-3. If the anthropogenic disturbances as mentioned above are continued in these ponds, it is likely that in near future these ponds would turn to eutrophic and then highly eutrophic systems which are undesirable not only for human use but also for the local environment, as these ponds might later on turn to breeding grounds of mosquitoes, snails and other pathogenic organisms. Therefore, there is a necessity to manage these ponds. The study also reveals that management of three ponds should take into consideration not only the disturbances within the ponds but also the disturbances in their surrounding land areas. For carrying out the management activities of these ponds, riparian people should be made aware of the fact and accordingly necessary management steps should be taken. 


\section{Acknowledgements}

The authors extend their appreciation to the Deanship of Scientific Research at King Khalid University for funding grant No. (R.G.P. 1/244/42).

\section{References}

Alfasane MA, Islam MS and Begum ZNT 2002. Association of Vibrio cholerae O1 and O139 with phytoplankton in a pond of Bangladesh. Bangladesh J. Bot. 31(1): 19-22.

Alfasane MA, Islam MS and Begum ZNT 2003. The relationship between Phytoplankton and some physicchemical variables in two ponds of Bakerganj. J.Asiat. Soc. Bangladesh (Sci.) 29(1): 93-102.

Alfasane MA, Gani MA, Islam MS and Khondker M 2012. Limnology of lakeAshura, Dinajpur, Bangladesh. Bangladesh J. Bot. 41(1): 43-48.

BAFRU 1990. A Survey of fish farm in Bangladesh. Univ. of Starting, Starting, Scotland. 92 pp.

Balasingh GRS 2010. Studied on phytoplankton diversity and seasonal abundance of a perennial pond in kanyakumari-Tamilnadu, Indian J. Basic Appl. Biol.4:188-193.

Banita DM, Tapati D and Susmita G 2013.Limnological studies of temple ponds in cachar District, Assam, North East India. Int. Res. J. Environ. Sci. 2(10): 49-57.

Begum ZNT and Alam MJ 1987. Plankton abundance in relation to physico-chemical variables in two ponds in Maijdee Court. Noakhali. J.Asiat. Soc. Bangladesh (Sci.) 13: 55-63.

Bhuiyan JR and S Gupta 2007. A comparative hydrobiological study of a few ponds of Barak Valley, Assam and their role as sustainable water resources. J. Environ. Biol. 28(4): 799-802.

Chowdhury AH and Mamun AA 2006.Physio-chemical conditions and plankton population of two fishponds in Khulna. Univ. J. Zool. Rajshahi Univ. 25: 41-44.

FAP-17 1993. Investigation of pesticide residue level in floodplain fish in Bangladesh. Interim Report Annex B, FAP 17. Fish.Stud.Pil.Proj. pp 1-13.

Jerin, S, Khondker M and Alfasane MA 2012. Limnology of a pond in old Dhaka: With particular reference to phytoplankton. United Kingdom, LAP LAMBERT Acad. Publ. ISBN: 978-3847325918, 104 pp.

Khondker M 1995.Limnological research in Bangladesh . In: Limnology in Developing Countries (Gopal, B. and R. G. Wetzel, eds.). Int. Sci. Publ., New Delhi, India. 271 pp.

Kumar P, Wanganeo A, Sonaullah F and Wanganeo 2012.Limnological study on two high altitude Himalayan ponds, Badrinath, Uttarakhand. Int. J. Ecol. 2(5): 103-111.

Mackereth FJH, Heron J and Talling JF 1978. Water analysis: some revised methods for limnologists. Freshwater. Biol. Assoc. Publ. 120 pp.

Marker AFH, Nusch EA, Rai H and Riemann B 1980.The measurement of photosynthetic pigments in freshwaters and standardization of methods: conclusions and recommendations. Arch. Hydrobiol. Beih. Ergebn. Limnol. 14: 91-106.

Müller R and Wiedemann F 1995. Die Bestimmung des Nitrats in Wasser. Jahrbuchfür Wasserchemie und Wasserreinigungstechnik. Verlag Chemie, Reinbek 12: 247-271.

Murphy J and Riley JP 1962. A modified single solution method for the determination of phosphate in natural waters. Analyt. Chem. Acta 27: 31-36.

Nishat A, Hussain Z, Roy MK and Karim A eds. 1993. Fresh water wetlands in Bangladesh: Issues and approaches for Management. IUCN, Gland, Switzerland. xii+ 283 pp.

Pramanik S, Khondker, M. and Alfasane MA 2011. Limnology of Bangshal Pond, Dhaka: Focuses on seasonality of phytoplankton. United Kingdom, LAP LAMBERT Aca. Publ. ISBN: 978-3847321217, 96 pp.

Smayda TJ 1992. Global epidemic of noxious phytoplankton blooms and food chain consequences in large ecosystems. In: Sherman KL, Alexander LM, Gold BD (eds), Food Chains, Models and Management of Large Marine Ecosystems. Westview Press, CO. 257-307 pp.

Wetzel RG and Likens GE 1979.Limnological analysis. W. B. Saunders Co., Philadel.. 357 pp.

(Manuscript received on 4 August, 2021; revised on 6 December, 2021) 